\title{
CHILDREN LEARNING A FOREIGN LANGUAGE BY DOING AND PLAYING
}

\author{
María Isabel Velasco Moreno \\ Department of Languages, Arts and Sports, University of Málaga (Spain)
}

\begin{abstract}
Since the last part of XX century there has been a great interest on Foreign Language (FL) acquisition. A lot of research has been done on Second Language Classrooms (Chaudron, 1988) and on how English learning can be improved (Ellis and Sinclair, 1989) big efforts have been made on making lessons more meaningful to students (Long \& Doughty, 2009). Special attention was given to learner's uptake (Bailey, 1991) although most of the studies have been carried out studying teacher's performance in class.

This research pretends to investigate the teaching learning context itself. Although taking into account all participants in class, the main focus is on learners. Taking discourse analysis as an essential tool (Sinclair \& Coulthard, 1992; Tsui, 1994; Poyatos, 1998; Velasco 2012) we study English classes for Spanish young learners aged 10-12.

We are interested in analyzing learners' oral output after using a different methodology. Believing that motivation, affect and students' emotional intelligence play an exceptional role on L2 learning (Arnold, 2006) as well as Cooperative Learning (Kagan, 2009; Slavin, 2014), our methodology has focused on promoting and helping students to create a game to play in and out of class, in big and small groups in order to improve their FL acquisition. We have studied students' participation and interaction level as well as their English acquisition level.

Results show very relevant information that could greatly help teachers and students from all educative levels.
\end{abstract}

Keywords: Cooperative Learning, gamification, classroom interaction, foreign language learning, didactics.

\section{Introduction}

Nowadays, it is extremely important to understand the teaching-learning process in the Foreign Language (FL) class at Primary level in order to improve FL acquisition. In Spain, children start to learn English as a foreign language at three in many schools but it is amazing the quantity of students that do not feel confident enough to speak in English when they leave Secondary school after 13 years studying a Foreign language. In contrast, in many European countries children start to learn a foreign language when they are older (12 years old), have less number of L2 tuition and are able to speak in English better when they leave Secondary schools. Teachers should reflect on the teaching-learning process and use effective methodologies for students in the changing world in which they are living.

\section{Objectives}

In spite of the great number of teaching aspects that need further research, we have opted for focusing on one of the most difficult grammar points to teach at schools: affirmative, negative and interrogative sentences in present tense with verbs to be, to have got, can and action verbs. After three decades teaching English as a foreign language to Primary school students, we have observed that Spanish students have great difficulties in learning and using properly simple present with usual action verbs and also with to be, to have got and can. It seems to be especially difficult for students to use the third person in singular (he/she/it/) in simple present.

Our main objective in this study is to analyze learners' oral output after using a different methodology when learning Simple present. We would like to know if using the new educative tool that we are going to name $30 Q$ mini-book helps students to learn better L2 and we also would like to know how they use it and what they think about it. 


\section{Design}

In order to help our students, we decided to create a new educative tool, the $30 \mathrm{Q}$ mini book, and use it with a different methodology in the foreign Language class. Believing that motivation, affect and students' emotional intelligence play an exceptional role on L2 learning (Arnold, 2011) as well as Cooperative Learning (Kagan, 2009; Slavin, 2014), our methodology has focused on promoting and helping students to create a game to play in and out of class, in big and small groups in order to improve their FL acquisition. We have studied students' participation and interaction level as well as their English acquisition level.

Fifty Spanish students aged 11-13 years old have participated in this study. They study English in Year 6 in the same school, located in a medium size city in Spain. 26 students belong to group A experimental group) and 24 students to group B (control group). The same English teacher has taught them for last three years. There is only one new student.

In both groups, students have studied Simple Present paying special attention to third person in singular but with different methodologies: in group B, using the communicative language teaching and doing activities from the text book and in group A, the teacher $(\mathrm{T})$ has used a new tool to learn a foreign language: the 30 Q mini-book.

After two weeks playing 30-Q game to guess the animal where one student stood in front of the class and answered his/her classmates' questions, we audio recorded students playing and analyzed data with a discourse analysis model (Velasco 2012), based on Sinclair \& Coulthard, 1992; Tsui, 1994; Poyatos, 1998. Relevant conclusions can be drawn from results.

\section{Method}

In order to motivate students in class, we propose a game in which students have to guess the animal one person has in his/her mind. One student is in front of the class, facing the group of students. $\mathrm{She} / \mathrm{He}$ writes the name of one animal in a piece of paper and gives it to the teacher. Then, this student answers all questions made by the rest of students. The person who guesses the animal comes to the front of the class and do the same. Learners have played the same game in both classes for two weeks.

In class $\mathrm{B}$, teacher explained how to make questions in English with verbs to be, to have got, can and action verbs with the same examples that students in class A included in their mini-book and all possible answers. Both had to study them. Methodology used in the experimental group had two different stages: In stage 1, students had to make the mini-book and in stage 2, play using it. Mini-books were not given to the students, they had to make them in class based on learning by doing theory (Williams,2017).

To make a mini-book students only need a sheet of paper. After folding it three times and cutting it in the middle, opening it and closing it students get a little book with eight pages on it. We used it to write useful sentences that we need to play a game to guess an animal.

The teacher played an essential part because she was in the blackboard delimiting 8 parts and writing the title in the first page: $M y 30-Q$ mini game and each student had to write his/her name, level and class. The reason why that title was chosen is because there are 26 students in class and being 30 questions the maximum, there is a possibility for all students to ask, at least, one question. Teacher and students are working at the same pace and all students complete the mini game at the same time. Teacher is asking questions like What would you like to ask? If students make a question in Spanish, teachers asks how would you say that in English? to students Then, learners have to say the possible answer to the yes/no question previously written. As there are seven pages plus the front page, teacher tries to make sure that there are questions containing is it? Has it got? Can it ...? or does it ...?

In each page of our $30 \mathrm{Q}$ Mini game appeared the following sentences:

2.- Has it got four legs?= ¿Tiene 4 patas? Yes, it has $=$ sí $/$ No, it hasn't $=$ No

3.- Has it got feathers? = ¿Tiene plumas? Yes, it has=Sí $/$ No, it hasn't $=$ No

4.- Has it got a tail $?=¿$ Tiene cola? Yes, it has $=$ Sí $/$ No, it hasn' $t=$ No

5.- Is it green? = ¿es verde? Yes, it is $=$ Sí/ No, it isn' $t=$ No

6.- Does it eat meat? = ¿Come carne? Yes, it does= Síl No, it doesn't $=$ No

7.- Does it live in the jungle?= ¿vive en la selva? Yes, it does $=$ Sí $/$ No, it doesn't= No

8.-Can it fly? = ¿Puede volar? Yes, I can= Sí/ No, it can=No

During the following two weeks, students in both classes played the game to guess an animal, using the $30 \mathrm{Q}$ mini game in class A and vocabulary and grammar points learnt in class in class B. After that time, learners where audio recorded. In class A, students were distributed in cooperative teams of 4 or 5 members and in class B learners played as usual, one student in front of all his/her classmates answered their questions. There is a maximum of 30 questions to guess the animal. Once who guesses it, student thinks of an animal and answer the questions. 
Data reveals relevant information. Table 1 and table show the amount of questions made by learners during five minutes audio recording in each class and the quantity of animals that students guessed in each class.

Table 1. Quantity of questions and animals guessed in class B.

\begin{tabular}{|c|c|}
\hline N. animals & N. of questions \\
\hline 3 & 39 \\
\hline
\end{tabular}

Table 2. Quantity of questions and animals guessed in class A.

\begin{tabular}{|c|c|c|c|c|c|c|}
\hline Class A & G1 & G2 & G3 & G4 & G5 & Total \\
\hline N. questions & 48 & 40 & 46 & 41 & 50 & 225 \\
\hline N. animals & 3 & 3 & 2 & 2 & 9 & 19 \\
\hline
\end{tabular}

Differences are clear. There is a higher interaction level in class A. In the same amount of time (5 minutes) students in class A made more than five times more questions than in class B. Furthermore, students from each cooperative team in class A participated actively. Within each group, students made more questions than the whole class of $6^{\text {th }}$ B. Taking into account that teams were formed by 4 or 5 members we can observe that each student had more opportunities to speak, asking or answering questions than in class B where only the highest achievers prompt to talk in public. On the other hand, we have analyzed discourse produced by team members as shown on table 3 .

Table 3. Data analysis group 4, class A.

\begin{tabular}{|c|l|l|}
\hline line & Student's discourse & Communicative acts \\
\hline 1 & S3.- It is big? & I3(elic:confirm) \\
\hline 2 & S2.-Yes, it is & R2(confirmation) \\
\hline 3 & S1.- Has it got four legs? & I1(elic:confirm) \\
\hline 5 & S5.- Is it tiger? & I5(elic:confirmation) \\
\hline 6 & S2.-No, it isn't & R2(confirmation) \\
\hline 7 & S1.- hair? & I4(elic:confirmation) \\
\hline 8 & S4.- (nods) hair? & I1(elic:conf) \\
\hline 9 & S2.-Yes, it has & NVR(confirmation)R4(repetition) \\
\hline 10 & S3.- long hair or short hair? & R2(confirmation) \\
\hline 11 & S2.-Short & I3(elic:inf) \\
\hline 12 & S5.- Does it meat? ...(he touches his hair) & R2(give inf) \\
\hline 13 & S1.- Does it eat meat? & I5(elic:conf) \\
\hline 14 & S5.- Does it eat meat? & I1(elic:repetition) \\
\hline 15 & S2.-Yes & R5(repetition) \\
\hline 16 & S4.-Is it a Wolf? & R2(confirmation) \\
\hline
\end{tabular}

G4 students' discourse. Own resource

In the first column, it is the order of sentences. In the second one, students' communicative discourse. S1 refers to student 1, S2 to student number 2 and so on. In the third column, we have analyzed each fragment of student's output into communicative acts according to the illocutionary force. As we can see, most of students' communicative acts belong to the Initiation Move that elicit confirmation and S2 always responds with a confirmation or a no confirmation act. Students use what they have learnt to do with their 30Q mini game, using the same sentences that appear in their little book but, surprisingly, on line 6, S4 tries to use a different sentence although he is not able to complete it and we can see how S1 tries to help. It is a clear case of scaffolding between students. Working in a cooperative team has taught them to be helpful with others. Again, on line 13, S1 helps another student (S5) when he understand what he tries to say and becomes a model for him. 
On the other hand, S3 feels ready to make his own question: long hair or short hair? In that case, S3 instead of eliciting confirmation, elicits information.

Nevertheless, some grammar mistakes are observed on lines 1 and 4 but, in spite of not being perfect, communication is clear and they keep on playing. As Kagan (2009) states It's all about engagement and we could observe engagement in all cooperative teams but there is no engagement on $6^{\text {th }}$ B class where some students are not paying attention, talking to their classmates in Spanish instead than in English. Only volunteer students take part in the game in class B. On the contrary, all students in class A participated as they were in small teams and they know that all team members have to participate.

According to mistakes, we have observed that some students in both classes got confused when making questions in third person with verb to be. E.g: It is big? Also some students forgot to include 'a' in questions like: Is it _ tiger? In class be, besides those mistakes, students got confused with Can I fly? Instead that Can it fly? Or Do you live in the jungle? instead of Does it live in the jungle?

On the other hand, to obtain learners' feedback on their mini game, they had to complete the following questionnaire where they had to fill, at least, one answer.

Question number one was: Have you ever made a 30-Q mini game? And, obviously a $100 \%$ answered yes because they all had to do it in class. The second question was What is it useful for? With four answers: a) to play; b) to read ; c) to study and d) to write. Students could mark more tan one answer and the result was: $100 \%$ used the little book to study it; 79 '2 stated that they used it to play; $29 \%$ considered that they read it and $25 \%$ said that it was useful to write it.

Question number 3 was Do you read your 30Q Mini game at home? The highest percentage $(62.5 \%)$ went to sometimes; $29 \%$ said that they never read it at home; 2 students said that they read it everyday and 2 students affirmed that they use it when a classmate comes to his/her house to play.

Nearly the whole class $(91.6 \%)$ answered Yes to question number 4: Do you think it is useful to learn English? Moreover, most students were conscious that they had learnt a lot with this new tool 83.3\% answered yes to the question Have you learnt with 30Q Mini game?

Question number 6 was What have you learnt? with different possibilities; a) to speak; b) to answer; c) to ask; d) to listen and e) to write. Most students $(83.3 \%)$ answered that they had learnt to ask and answer in English. 62.5\% stated that the had learnt to speak in English and 58.3\% considered that they had learnt to write in English.

Our final question, How did you learn more: making the mini game or playing with it?, showed very interesting results as $66.6 \%$ considered that playing, $25 \%$ making it and $8.4 \%$ chose both answers.

\section{Discussion}

We believe that observing how students learn is probably the best way to learn about the teaching-learning process. Teachers occupy the most relevant part in this task because they cannot only observe but also act and observe results when implementing different methodologies. Action research is needed in our schools because students need to get in contact with new ways to learn a foreign language. Most Spanish students are not eager to learn a foreign language and teachers have to motivate them. New methodologies always attract learners' attention. Games are always welcome in the FL class but they need language support to use L2 language as a vehicle for playing. Despite most learners are not conscious of how useful is to do their own made $30 \mathrm{Q}$ mini game, in doing it they have thought about useful sentences and learnt how to build them which helps them to create similar sentences.

\section{Conclusions}

This study has shown great differences in the FL class depending on the methodology used. Cooperative learning gives students more opportunities to participate and interact in the foreign language. The new tool, 30Q mini game, has been a great asset for students. First of all, they have made their own sentences using their thinking skills. Now, they are prepared to make many more questions and are able to answer them. They do not have to keep on asking the teacher: how do you say...? On the contrary, they start using sentences from the mini book fluently and very soon, they make new questions because they have learnt how to do it.

Our first conclusion is that children are eager to use new learning tools and welcome any active methodology pursuing learners' interaction. Not only better results were observed when using the mini game, but also more students' output in English, less grammar mistakes, more fluency in the foreign language, more engagement and what is more important, we could see students coaching their classmates, learning cooperatively. 


\section{References}

Arnold,J (2011) Attention to Affect in Language Learning. Anglistik. International Journal of English Studies.

Bailey, K. M. (1991) 'Diary studies of classroom language learning: the doubting game and the believing game'. In E. Sadtono (ed) Language acquisition and the second/foreign language classroom. Singapore. SEAMO, RELC, series 28.

Chaudron, C. (1993) Second Language Classrooms. Cambridge. Cambridge University Press.

Ellis, B \& Sinclair, J. (1989) Learning to learn English. C.U.P.

Johnson, D. W. \& Johnson, R. T. (2013). The impact of cooperative, competitive, and individualistic learning environments on achievement. In J. Hattie \& E. Anderman (Eds.), International handbook of student achievement (372-374). New York: Routledge.

Kagan, S. (2009). Kagan Cooperative Learning. San Clemente, CA. Kagan Publishing.

Poyatos, F. (1998) Paralenguaje: a linguistic and interdisciplinary approach to interactive speech and sound. Amsterdam: John Benjamins.

Slavin, R. (2014) Cooperative Learning and Academic Achievement: Why Does Groupwork Work? Anales de Psicología. DOI: https://doi.org/10.6018/analesps.30.3.201201

Sinclair, J.M. \& Coulthard, M. (1992) 'Towards an analysis of discourse' en Coulthard, M (ed) Advances in spoken Discourse Analysis. London: Routledge 1-31.

Tsui, A.M.B. (1994) (1994) English Conversation. Oxford. Oxford University Press

Velasco, M.I. 2012 Investigating participation level in Foreign Language Classrooms through the analysis of communicative discourse. Porta Linguarum, 17: págs. 47-65. (2012)

Williams, M.K. (2017) John Dewey in the 21 st Century. Journal of Inquiry \& Action in Education, 9(1). 